\title{
Evaluation of the Fertility Status of Pomegranate Orchard Soils of Jalna District, India
}

\author{
A.B. Patil*, S.S. Mane and A.V. Chaudhari \\ Department of Soil Science and Agricultural Chemistry, College of Agriculture, Badnapur, \\ Vasantrao Naik Marathwada Krishi Vidyapeeth-431402 (M.S.), India \\ *Corresponding author
}

\section{A B S T R A C T}

\section{Keywords}

Chemical properties, Nutrient index,

Pomegranate orchard growing soils

\section{Article Info}

Accepted:

28 March 2018

Available Online:

10 April 2018
The present investigation evaluation of soil fertility status of pomegranate orchard by soil in Jalna district for this purpose collected representative soils from the selected sixty orchards. The pomegranate orchard soils were neutral to alkaline in reaction and electrical conductivity of pomegranate orchard soil was in safe limit for the crop growth. These soils were highly calcareous in nature and low to medium in organic carbon. The soils are categorized as low in Nitrogen and Phosphorus as well as high in potassium content in pomegranate orchard soils of Jalna district. These soils were low to medium in available $\mathrm{Fe}$ and $\mathrm{Zn}$ content and high in $\mathrm{Mn}$ and $\mathrm{Cu}$ content pomegranate growing soils of Jalna district.

\section{Introduction}

The natural resources (soil, climate features and water) profoundly influence the cropping pattern and crop productivity in specified region. Literally the lands for agriculture are under a threat due to multisectoral demand, severe soil degradation and conversion of good fertile land for civilian and other infrastructural development. There is a remote possibility of expanding agriculture to new areas in the country. It has been observed that the per capita land availability decreased from 0.48 ha in 1951 to 0.26 ha in 1981 and has further decreased to 0.14 ha during 2000 . It may narrow down to 0.09 ha by 2020 A.D. It is therefore imperative that the land resources need to be interpreted in terms of their suitability for different agricultural uses with a view to maximize production of food, fuel and fiber. In Jalna district Pomegranate is grown on different soil types viz. very deep soil, moderately deep soil, shallow and very shallow soil. The present yield of heavy textured soil is much below the optimum yield. The suitability of soil and economic viability are the two important aspects which can guide the farmer's improper site selection and management of Pomegranate orchards to bring down the cost of production. In order to increase the area under production of Pomegranate, it is necessary to take up the 
intensive study of soil to ascertain soil parameter responsible for influencing productivity. For increasing the productivity and quality of fruit, it should have suitable for soil quality and environment and it is of prime importance to characterize and evaluate the soil site characteristics which are dynamic and complex attributes that directly influence the growth and performance of Pomegranate. Therefore, a comprehensive study was undertaken to know the fertility status of pomegranate growing soils of Jalna district.

\section{Materials and Methods}

\section{Description of study area}

The study area of Jalna district is located in the central part of Maharashtra state in the Marathwada region. It lies between $19^{\circ} 1^{\prime}$ to $20^{\circ} 3^{\prime}$ North latitudes and $75^{\circ} 4^{\prime}$ ' to $76^{\circ} 4^{\prime}$ ' East longitudes.

The Jalna district has a sub-tropical climate in which the bulk of rainfall is received from south west monsoon during June to September. The maximum temperature rises to about $41{ }^{0} \mathrm{C}$ in the month of May while the lowest temperature is recorded in the month of December which is about $9^{0} \mathrm{C}$. The total geographical area of the district is 7,612 sq $\mathrm{km}$. constituting $2.51 \%$ of the total state. The current irrigation potential in the district is 66,097 ha while the area under well irrigation is about 35,000 ha.

The area under double crops is $15 \%$ while the area under irrigation is only $7.8 \%$ which is far below the state average. The Godavari, Purna and Dudhana are the 3 major rivers which flow through the district. The river Godavari flows along the southern boundary of the district in west to east direction. The Godavari and its tributaries drain dendrites pattern the southern part of the district and occupy $30 \%$ of the area.

\section{Collection of soil samples}

In order to studies on assessing fertility status of different villages of Badnapur, Jalna, Mantha, Partur, Jafrabad Tahsils of Jalna district, and sixty representative surface (0-30 $\mathrm{cm})$ soil samples were collected, ground and passed through $<2 \mathrm{~mm}$ sieve and stored in properly labeled plastic bags and characterized for chemical properties of soils. The soil pH, EC, Organic Carbon and available Phosphorus by using spectrophotometer were estimated by the standard procedure as described by Jackson (1973). Calcium carbonate and Available Potassium by using of flame photometer as per procedure described by Piper (1966). The available $\mathrm{N}$ was analyzed by using alkaline potassium permanganate (Subbiah and Asjia, 1956). DTPA (0.005 M) extractable Zinc, Iron, Manganese and Copper content of soil were analyzed by using Atomic Absorption Spectrophotometer (AAS) as per the procedure outlined by Lindsay and Norvell (1978).

\section{Results and Discussion}

The result of study indicated that $\mathrm{pH}$ value of orchard soils varied from 7.0 to 8.5 with an average value 7.86 which indicate that these soils were neutral to alkaline in reaction. The alkaline reaction is probably due to the presence of sufficient free lime content (Kaushal et al., 1986) and basalt alluvial parent material rich in aluminosilicate alkaline earth from which these soils are derived (Challa et al., 1998) Electrical conductivity of pomegranate orchard soils varied between 0.27 to $0.72 \mathrm{dSm}-1$ with mean value of $0.48 \mathrm{dSm}-1$ As per categorization of pomegranate orchard growing soils, all the soil samples $100 \%$ were found safe in EC for pomegranate production. The organic carbon content in pomegranate orchard soils was ranged from 0.18 to 1.07 per cent with an 
average value of 0.55 per cent and data further revealed that overall pomegranate orchard growing soils were low to medium in organic carbon content is might be due to soil erosion and poor management of soil. According to Velayutham et al., (2000) organic carbon range from low to medium in black soils (shrink-swell soils) of arid and semi-arid climate due to large surface area of the dominant minerals of these soils. The $\mathrm{CaCO} 3$ content were varied in the range of 4.3 to $20.5 \mathrm{~g} \mathrm{~kg}-1$ with mean value of $12.09 \mathrm{~g}$ $\mathrm{kg}$-1.According to categorization, it was observed that pomegranate orchard growing soils of Jalna district were calcareous to highly calcareous in nature. It might be due to relatively more accumulation of $\mathrm{CaCO}_{3}$ in Vertisols and associated black soil may be partly associated with their recent origin with rich in alkali earth and partly due to calcification process prevalent in this region and the pomegranate orchard growing soils were categorized for macro and micro nutrients viz, $\mathrm{N}, \mathrm{P}, \mathrm{K}, \mathrm{Zn}, \mathrm{Fe}, \mathrm{Mn}$ and $\mathrm{Cu}$ according to norms suggested by Parkar (1951). The available $\mathrm{N}$ were found in between 98.56 to $250.64 \mathrm{~kg} \mathrm{ha}^{-1}$ with an average of $155.67 \mathrm{~kg} \mathrm{ha}^{-1}$, The data further showed that 100 per cent soil samples were found low in available nitrogen The lower content of available nitrogen in these orchard growing soils are associated with hot and dry climate. Low content of organic matter and total nitrogen reserve and in term $\mathrm{C}: \mathrm{N}$ ratio of immobilized form of nitrogen (Malewar, 1995). The available $P$ were found in between 6.53 to $24.70 \mathrm{~kg} \mathrm{ha}^{-1}$ with an average of 11.01 $\mathrm{kg} \mathrm{ha}^{-1}$. The low available phosphorus might be due to the higher phosphorus fixing capacity of black cotton soils of Jalna district that prevent the soil phosphorus to come in soil solution. The swell - shrink soils of Maharashtra were very low to high in available phosphorus. The available K 98.54 to $999.30 \mathrm{~kg} \mathrm{ha}^{-1}$ with an average $591.34 \mathrm{~kg}$ $\mathrm{ha}^{-1}$. The high content of $\mathrm{K}$ is due do presence of potassium rich mineral in Vertisol and associated black soils Chaudhari and Kadu (2007). Micronutrient content in pomegranate orchard growing soils are available $\mathrm{Zn}$ were found in between 0.31 to $2.17 \mathrm{mg} \mathrm{kg}^{-1}$ with the mean value of $0.77 \mathrm{mg} \mathrm{kg}^{-1}$. The soils were found to be low to medium in $\mathrm{Zn}$ content and this might be due to the fact that in a welldrained, aerated, calcareous soil, Zn exists in oxidized state and its availability becomes low. The available Fe were found in between 0.12 to $0.46 \mathrm{mg} \mathrm{kg}^{-1}$ with the mean value of $0.23 \mathrm{mg} \mathrm{kg}^{-1}$ The result of the pomegranate soils were low to medium in available $\mathrm{Fe}$ content. The available $\mathrm{Mn}$ were found between 2.39 to $50.60 \mathrm{mg} \mathrm{kg}^{-1}$ with the mean value of $8.32 \mathrm{mg} \mathrm{kg}^{-1}$. The high $\mathrm{Mn}$ status in these soils might be due to the lower oxidation state of $\mathrm{Mn}$ are more soluble than higher oxidation state at normal $\mathrm{pH}$ of soil. The available $\mathrm{Cu}$ were found in between 4.57 to $17.29 \mathrm{mg} \mathrm{kg}^{-1}$ with mean values of 12.54 $\mathrm{mg} \mathrm{kg}^{-1}$.The low copper contents in pomegranate orchard growing soils might be due to the absence of copper bearing minerals like cuprite and chalcolite in the parent material.

Pomegranate growing soils are neutral to alkaline in $\mathrm{pH}$ and safe limit of EC. But highly calcareous in nature. These soils are contenting low to medium organic carbon, low in available nitrogen and phosphorus and high in available potassium. The available manganese and copper were high whereas, available iron and zinc were low to high in soils.

\section{References}

Challa, O., Vadivelu, S. and Sehgal, J. L. (1998). Soils of Maharashtra for optimizing land use. NBSS Pub: 54 (soils of India series) NBSS and Land Use Planing Nagpur, India PP: 112. 
Chaudhari, R. D. and Kadu, P. P. (2007). Assessment of fertility status of the soils of Dhule tehsil of Dhule district. Paper presented in state level seminar on soil health enhancement for food and environmental security, organized by PCISSS, at Marathwada Agril Uni. Parbhani. Oct 12 \& 13. 2007 Abst. PP 2

Jackson, M. L. (1973). Soil chemical analysis, Prentice Hall of India Pvt. Ltd. New Delhi, pp-498.

Kaushal, G. S., Tembare, B. R. and Sinha, S. B. (1986). Morphology and taxonomy of black soil under bargi irrigation project in Madhyapradesh. J. Indian Soc. Soil Sci., 34 (2): 329-333.

Lindsay, W. L. and Norvell, W. A. (1978). Development of DTPA soil test for Zn,
$\mathrm{Fe}, \mathrm{Mn}$ and Cu. Soil Sci. America. J. 42: 421-428.

Malewar, G. U. (1995). Micronutrient availability as influenced by cropping pattern in Marathwada region of Maharashtra.J. Maharashtra Agric. Univ., 20 (2): 330-333.

Piper, C. S. (1966) Soil and Plant Analysis, IVth Edn. 135-200 Univ. of Adeleide, Australia.

Subbiah, B. V. and Asija, G. L. (1956). Rapid procedure for the determination of available nitrogen in soil. Curr. Sci., 25: 259-260.

Velayutham, M., Pal, D.K. and Bhattacharya, T. (2000). Organic carbon stock in soils of India. Global climate change and tropical ecosystems, 71-95.

\section{How to cite this article:}

Patil, A.B., S.S. Mane and Chaudhari, A.V. 2018. Evaluation of the Fertility Status of Pomegranate Orchard Soils of Jalna District, India. Int.J.Curr.Microbiol.App.Sci. 7(04): 34173420. doi: https://doi.org/10.20546/ijcmas.2018.704.386 